\title{
POLITICAL PARTISANSHIP \\ AND CORPORATE PERFORMANCE
}

Art Durnev - University of lowa

Jon Garfinkel - University of lowa

Sasha Molchanov - Massey University

Institute for Study of Competition and Regulation

June 6, 2012 


\section{Motivation}

- Left parties have often been viewed by economists (and general public) as less "business-friendly"

- Higher taxes (Alesina, 1987; Budge et al., 2001)

- Higher interest rates (Alesina and Rodrick, 1994; Snowberg et al., 2007)

- Stringent labour regulation (Botero et al., 2004; Rueda, 2005)

- Strict environmental regulation (Shipan and Lowry, 2005; Neumayer, 2004; Budge et al., 2001) 


\section{Mixed Evidence}

- Mixed academic evidence on the impact of partisanship on financial outcomes

- Santa Clara and Valkanov (2003, JF) - significantly higher stock returns under Democratic presidencies

- Jacobsen and Stangl (2007) - no presidential cycle in US industry returns.

- Snowberg, Wolfers, and Zitzewitz (2007, QJE) - higher equity prices, interest rates, and US dollar exchange rates under Republican presidencies

- Pinto and Pinto (2008) - under left governments, FDI inflows have a positive impact on wages 


\section{Motivation}

- Lack of conclusive evidence is particularly puzzling given growing literature on the impact of political uncertainty on financial outcomes

Julio and Yook (2012, JF); Boutchkova, Doshi, Durnev, and Molchanov (2012, RFS); Pastor and Veronesi (2011, JF)

- There is a material impact of uncertainty regarding party orientation and policies

- However, no consistent evidence that firms perform worse under left governments

- Simple test: Compare ROAs in country-years of left and right governments

- No significant differences in performance 


\section{Motivation}

-Why?

1. Not all firms are equally exposed to influence of 'leftist' policies

2. Not all 'leftist' legislation is enacted under left governments

3. Much of the existing literature has relied in a 'left-right' dummy variable 


\section{Our Contribution}

1. Explicitly account for the fact that not all industries are equally influenced by government partisanship

- Introduce several measures of 'leftist' sensitivities

2. Acknowledge the imperfect link between orientation of a ruling party orientation and actual policies

- Perform a two-stage regression. Use policies explained by party orientation

3. Account for potential complexities of government structures (e.g., coalition governments, legislative and executive branches controlled by different parties)

- Create a novel party orientation index 


\section{Our Contribution}

4. Perform the study in an international context

- Much of the evidence is based on US data

5. Address endogeneity between performance and party orientation

- $\quad$ Aside from "standard" remedies for endogeneity, we create a novel instrument of party orientation - commodity resource endowment

- High resource endowment prompts redistributive pressures, making left governments more likely

- $\quad$ Note that this instrument is time varying 


\section{Political Orientation Sensitivities}

- We hypothesize that not all firms are equally affected by government ruling party orientation

- Concept of 'political sensitivities' has been utilized before.

- Julio and Yook (2012) - more politically-sensitive industries experience sharper drop in investments in election years

- Boutchkova, Doshi, Durnev, Molchanov (2012) - more labourintensive, trade-dependent, and contract-dependent industries have higher volatilities in times of high political risk

- Belo, Gala, and Li (2011) - industries more dependent on government purchases perform better under Democratic administrations

- Large lobbying literature (e.g., Coper, Gulen, and Ovtchinnikov (2010) - stronger positive effect for firms contributing to Democrats) 


\section{Political Orientation Sensitivities (Contribution 1)}

- We propose four economic channels of leftist policies transmission.

- Sensitivity to labour legislation

- Measured by firms labour intensity as value of labour inputs over the total value of production inputs. US data - extrapolated on other countries (Similar to the methodology of Rajan and Zingales, 1997, AER).

- US labour laws are actually some of the most lax in developed world

- Sensitivity to tax legislation

- Measured by EBIT/Sales. Local data.

- Sensitivity to interest rates

- Measured by leverage (Total debt/Total assets). US data - extrapolated on other countries. 


\section{Rajan-Zingales Approach}

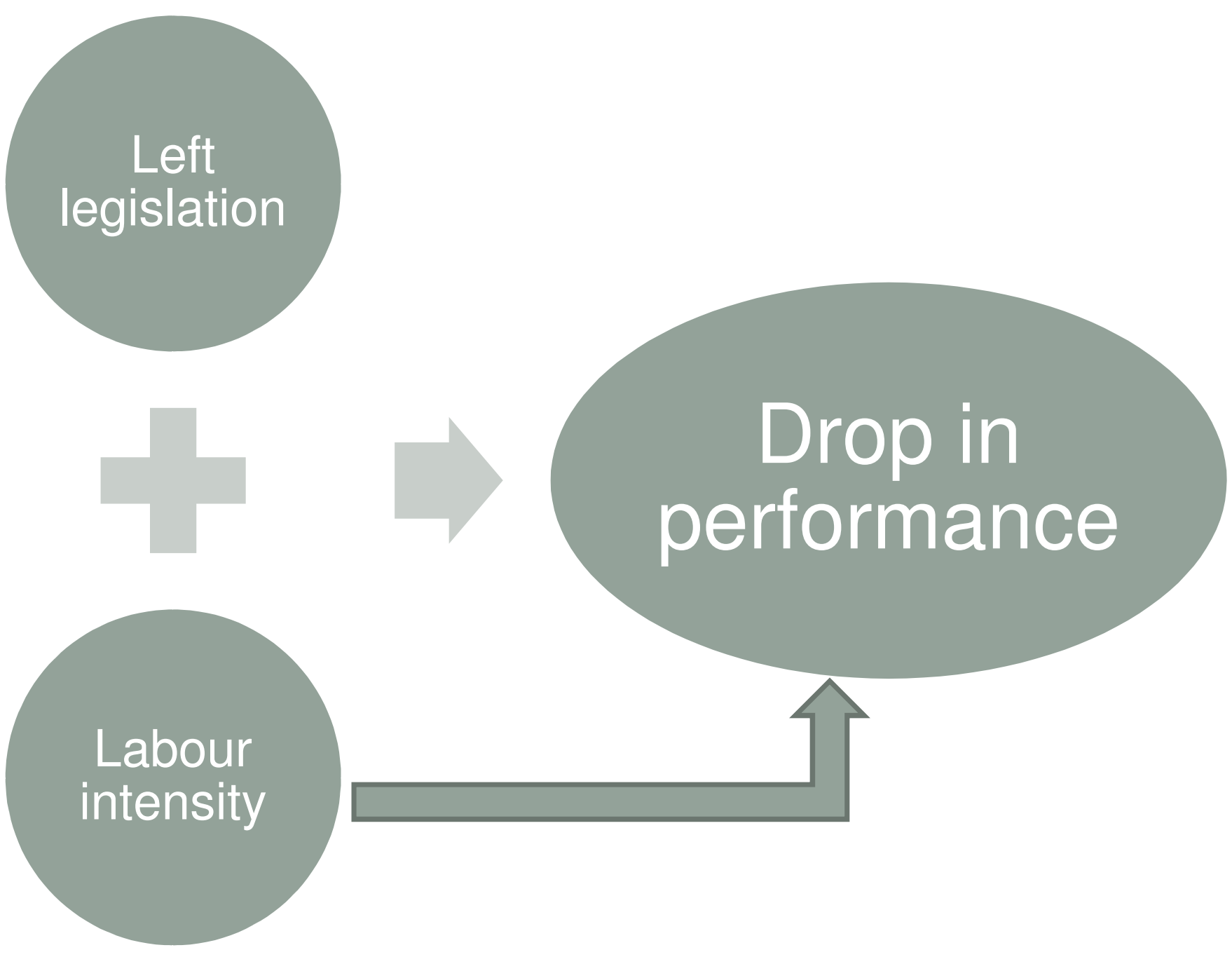




\section{Rajan-Zingales Approach}

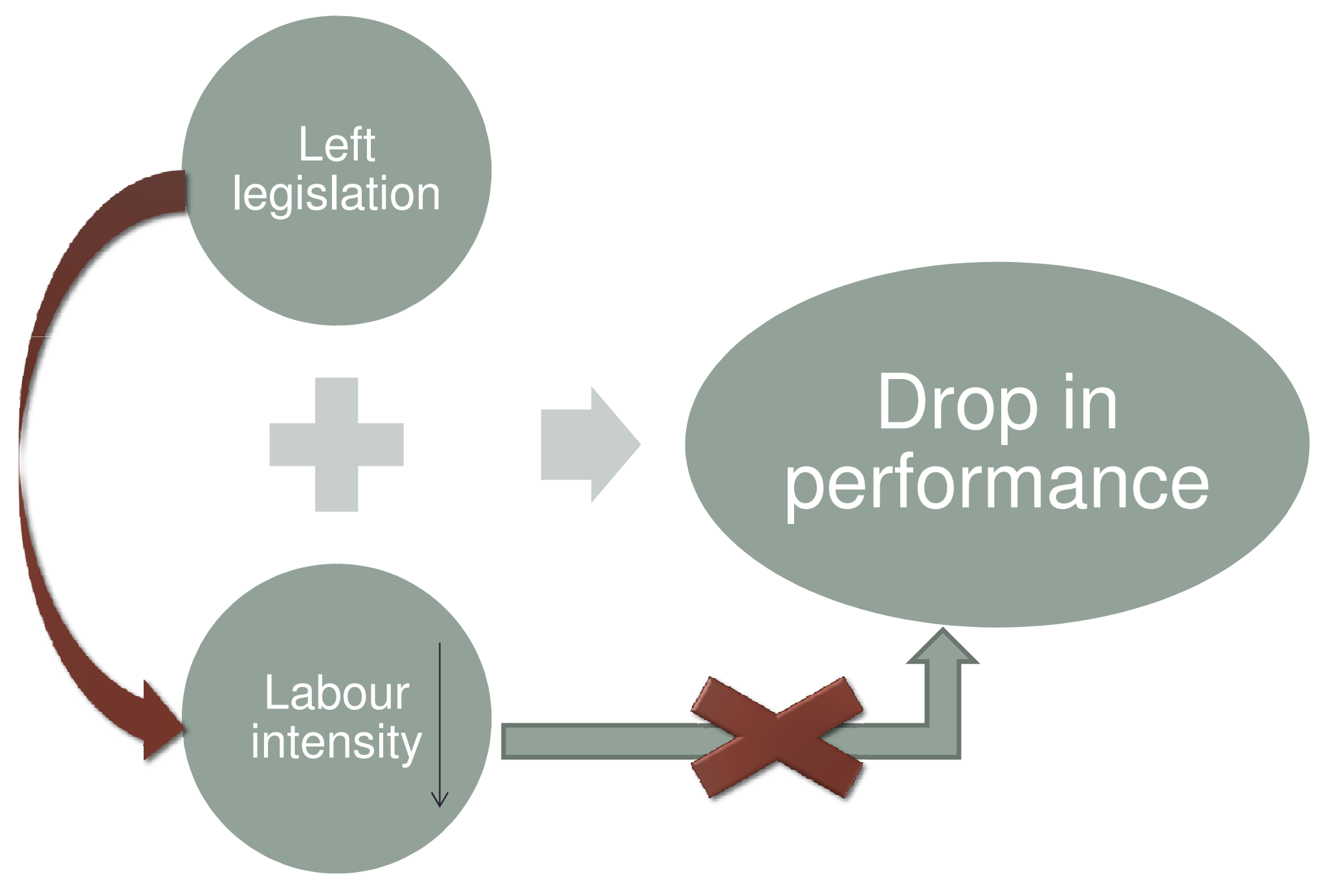




\section{Political Orientation Sensitivities - Continued}

- Four economic channels (continued):

- Sensitivity to environmental legislation

- Measured by environmental category of the Social Corporate Responsibility index compiled by MSCI ESG database. Canadian data extrapolated on other countries.

- Canadian environmental laws are relatively lax

- Sensitivity approach reduces omitted variable bias, as industries are compared within each country

- Alternative sensitivities are certainly possible 


\section{Link Between Party Orientation and Policies (Contribution 2)}

- It has been traditionally assumed that 'left' governments are associated with 'leftist' policies

- Botero et al, 2004; Rueda, 2005 - more stringent labour legislation.

- Alesina and Rodrick (1997), among others - higher interest rates.

- Alesina (1987) - higher taxes.

- Shipan and Lowry, 2001; Neumayer, 2004 - more stringent environmental laws.

- However, left party orientation is not always a good predictor of 'leftist' legislation (Pagano and Volpin, 2005; Bobbio, 1996; Faust and Irons, 1999; Hibbs, 1977)

- Our solution: employ two-stage least squares estimation and employ 'leftist' legislation explained (and unexplained) by party orientation 


\section{Link Between Party Orientation and Policies - Continued}

- Strength of 'leftist' legislation measures are regressed on the measure of left party orientation

- Fitted values and residuals are collected and used in the second stage regression

- The following policy measures were employed:

- Rigidity of employment legislation. Source: Doing Business Report (World Bank)

- Rigidity of environmental legislation. Source: IMD's World Competitiveness Report

- Corporate tax rate. Source: World Bank

- 90-day real interest rates. Source: WDI (World Bank) 


\section{Party Orientation Definition (Contribution 3)}

- Most of the existing literature relies on the indicator variable for left party orientation

- Currently, US ruling party would be classified as 'left', even though Congress is Republican

- Richer measures have been developed in political science (e.g., Woldendorp et al., 1993), but rarely applied in economics and finance literature (Arin, Molchanov, and Reich, 2012).

- We employ two alternative measures

- Percentage of seats in legislature held by left parties (Kim and Fording, 2002)

- Five-point scale ( $1=$ right, $5=$ left). Based on Woldendorp et al. (1993), supplemented by Leblang and Mukherjee (2005)

- Raw data obtained from World Bank's Database of Political Institutions 


\section{Party Orientation Definition - Continued}

- Five-point scale is defined as follows

1. Presidential system: president is 'right' AND controls houses with legislative powers. Parliamentary system: chief executive is 'right', AND government party controls more than $2 / 3$ of the parliament. (Right-wing dominance)

2. Presidential system: president is 'right' but does NOT control houses. Parliamentary system: chief executive is 'right' AND government party controls between $1 / 3$ and $2 / 3$ of the parliament.

3. Both systems: chief executive is 'centrist'.

4. Presidential system: president is 'left' but does NOT control houses. Parliamentary system: chief executive is 'left' AND government party controls between $1 / 3$ and $2 / 3$ of the parliament.

5. Presidential system: president is 'left' AND controls houses. Parliamentary systems: chief executive is 'left' AND government party controls more than $2 / 3$ of the parliament. (Left-wing dominance) 


\section{Hypothesis}

- We expect firms that are more sensitive to leftist policies will perform worse when left parties are in power and enact such policies.

- More specifically, labour intensive firms, firms with high gross profit margins firms with higher leverage, and firms emitting high quantities of pollutants are expected to perform worse and experience lower returns under left governments 


\section{Data Scope}

- Annual industry-level data, 1990 - 2009, 50 countries

- Industries are aggregated at the three-digit SIC level

- On average, in a given year, the sample contains 126 industries

- US data obtained from COMPUSTAT/CRSP

- International data based obtained from OSIRIS

- Control variables included:

- Log of total assets; R\&D spending/Total assets; growth in sales 


\section{Dependent Variables}

-Industry Value

- Measured by Tobin's Q (market value of equity and assets less book value of assets over total assets). Source: Worldscope.

-Takes into account current performance as well as future growth opportunities.

-Accounting Performance -Measured by ROA. Source: Worldscope.

-Reflects realized performance.

-Stock Returns

-Industry value-weighted average of annual firm returns. Source: Datastream. 


\section{Empirical Specification}

$D E P_{-} V A R_{i, j, t}=\alpha_{i}+\eta_{j}+\mu_{t}+\beta \cdot S E N S I T I V I T Y \times L E F T_{i, j, t}$

$+\lambda \cdot \operatorname{SENSITIVITT}_{i, j, t}+\theta \cdot \operatorname{LEFT}_{i, t}+\gamma \cdot \operatorname{CONTROLS}_{i, j, t}+\varepsilon_{i, j, t}$ 


\section{Results: A Synopsis}

\begin{tabular}{|c|c|c|c|c|c|}
\hline & & \multicolumn{4}{|c|}{ SENSITIVITY } \\
\hline & & Labour & Tax & $\begin{array}{c}\text { Interest } \\
\text { Rate }\end{array}$ & Environm. \\
\hline \multirow{3}{*}{ MEASURE } & Tobin's Q & $-0.101^{\star \star \star}$ & -0.093 & $-0.276^{\star}$ & $-0.013^{\star \star *}$ \\
\hline & Returns & $-0.027^{\star \star *}$ & $-0.078^{\star *}$ & $-0.094^{\star *}$ & $-0.004^{\star}$ \\
\hline & ROA & $-0.017^{\star * *}$ & $-0.114^{\star * *}$ & -0.099 & $-0.010^{\star * *}$ \\
\hline
\end{tabular}




\section{How "Left" is Left?}

\begin{tabular}{|c|c|c|c|c|}
\hline & $\begin{array}{c}\text { Strictness of } \\
\text { labour laws }\end{array}$ & $\begin{array}{c}\text { Strictness of } \\
\text { environmental } \\
\text { legislation }\end{array}$ & Tax rate & $\begin{array}{c}\text { Real } \\
\text { interest } \\
\text { rate }\end{array}$ \\
\hline Left Party Orientation Index & $\begin{array}{c}\mathbf{0 . 0 3 1} \\
\mathbf{( 0 . 0 6 )}\end{array}$ & $\begin{array}{c}\mathbf{0 . 0 1 6} \\
\mathbf{( 0 . 1 0 )}\end{array}$ & $\mathbf{3 . 0 3 8}$ & 1.122 \\
& & $\mathbf{( 0 . 0 5 )}$ & $(0.12)$ \\
\hline
\end{tabular}




\section{How "Left" is Left?}

- Summary of results (policy measures EXPLAINED by ruling party orientation)

\begin{tabular}{|c|c|c|c|c|c|}
\hline & \multicolumn{4}{|c|}{ SENSITIVITY } \\
\hline & & Labour & Tax & $\begin{array}{l}\text { Interest } \\
\text { Rate }\end{array}$ & Environm. \\
\hline \multirow{3}{*}{ MEASURE } & Tobin's Q & $-0.128^{\star \star \star}$ & $-0.076^{*}$ & $-0.513^{\star \star \star}$ & $-0.052^{\star}$ \\
\hline & Returns & $-0.016^{*}$ & $-0.045^{\star *}$ & $-0.131^{\star \star \star}$ & $-0.040^{\star \star}$ \\
\hline & ROA & -0.014 & $-0.020^{\star \star \star}$ & $-0.116^{\star}$ & $-0.009^{\star \star \star}$ \\
\hline
\end{tabular}




\section{Other Results of Note}

- Some sensitivity LEVELS are positively related to performance measures

- Tax rate sensitivity. Higher tax sensitivity, by definition, signifies improved performance

- Environmental sensitivity. 'Dirtier' industries minimize costs and increase value.

- Interest rate sensitivity. Highly leveraged industries outperform (may use debt to finance positive NPV projects)

- Effects are reversed when left governments are in power

- Sensitivities are detrimental only when they are conditioned on political environment 


\section{Other Results of Note}

-What about stock price reactions to elections of left governments (presumably negative)?

- We perform event study around election dates

- When left parties win, $\underline{C A R(-1,+1)=-1.36 \%}$ *

- Right parties win, CAR $(-1,+1)=0.75 \%$

- This is consistent with our expectations

- Winning margin is defined as (\% of votes in a winning coalition - \% of votes for opposition)

- Interaction of 'left winner' dummy with winning margin is positive and significant

- Wide margin -> No surprise -> No dramatic reaction 


\section{Robustness I: Reverse Causality}

- Possibility of reverse causality between party orientation and firm performance.

- However:

- Differences in firm performances within a country are less likely to affect electoral outcomes

- Explicitly address endogeneity concerns:

1. Control for past economic performance (include a number of lagged economic variables)

2. Perform the analysis on sub-samples of presidential and parliamentary systems

3. Regress left party indicator on past economic variables and use fitted values in interactions

- Preliminary results indicate robustness 


\section{Robustness II: Instrumenting Political Environment}

- Size of labour unions (left parties are more likely to be in power when unions are large).

- Resource (oil) endowment

- Left parties are more likely to be in power when pressure for redistributive policies is high

- Country-level resource endowment should not be systematically related to differences in industry performance Instrument is not weak (F-test $>10$ ) and exogenous

Results are also robust when other resources are used as instruments

- Preliminary results indicate robustness 


\section{Robustness III: Interest Rate Channel}

- We expect the impact of left governments to be stronger in countries with lower degree of central bank independence

- Country-years are ranked by degree of central bank independence

- Analysis is performed on top and bottom quartiles

- Substantially stronger effect for country-years with low degree of central bank independence 


\section{Robustness IV: Multinational Corporations}

- Firms have an option to shift their operations abroad through foreign subsidiaries

- Such a shift could be made due to political reasons

- This should work against significance of our findings

-We calculate industry shares of foreign subsidiary sales

- Positive and significant in most specifications

- This is expected: Less pronounced effect for industries with relocation options

- Main results remain robust 


\section{Robustness V: Political Connections}

- It could be argued that political connections, rather than partisanship plays a central role in determining firm performance

- Political connections are difficult to estimate in an international setting

- We use state ownership defined as percentage of common shares held by the state

- Coefficient on this variable is positive in some specifications

- Limited support to the conjecture that state-owned firms are less affected by value-destroying policies

- Main results remain robust 


\section{Robustness VI: Other issues}

- Firms may evade taxes

- Likely that firms with largest tax liabilities will be more actively engaged in tax evasion

- Explicitly account for evasion (tax rate times income minus reported tax liability)

- Results remain robust

- Firms may hedge interest rate risk

- Use percentage of firms that use interest rate and exchange rate derivatives as an estimate of hedging activity

- Insignificant. Main results remain robust

- Relationship can be different in developed vs. emerging economies

-We split the sample. Results hold 


\section{CONCLUSIONS}

- Despite common view of left parties being less businessfriendly, evidence of firms performing worse under left governments is, at best, mixed

- We contribute to the literature by

1. Introducing sensitivities to leftist policies

2. Addressing the fact that not all 'leftist' legislation is enacted by left governments

3. Refining the definition of 'left'

\section{Party orientation plays a significant role in} determining firms' performance!

- Industries more sensitive to leftist policies perform worse when left parties are in power and enact such policies.

- Results are robust when endogeneity is addressed 